\title{
Infrastructures as Ontological Experiments
}

\author{
CASPER BRUUN JENSEN
}

Leicester University

ATSURo MORITA ${ }^{2}$

Osaka University

\begin{abstract}
Ontology has recently gained renewed attention in science and technology studies and anthropology (e.g. Gad, Jensen and Winthereik 2015; Holbraad, Pedersen and Viveiros de Castro 2014; Woolgar and Lezaun 2013). Yet, it has a considerably longer pedigree than these recent debates might lead one to think. Experiments, of course, have long held the attention of sociologists, historians, and philosophers of science (Collins 1985; Gooding 1990; Shapin and Schaffer 1985). And infrastructures have been the focus of sustained inquiry in the sociology and history of technology (Bowker 1994; Hughes 1983). Once these terms are put into conjunction, however, each gets a somewhat different inflection. The following note briefly explores the conceptual purchase of considering infrastructures as ontological experiments.
\end{abstract}

\section{Keywords}

experiments; infrastructures; practical ontologies

\section{Practical Ontologies}

Although the term ontology has only recently been subject to sustained discussion, it has long operated as a kind of undercurrent in STS. We find ontological traces, if not the word itself, in Bruno Latour's (1988) "Irreductions." Early on Michael Lynch and Joan Fujimura both recognized that actor-network theory was something more and different than another social theory. While Fujimura (1991) approvingly referred to ANT as defining a new ontology, Lynch (as cited by Latour (1999a: 19) proposed, somewhat mockingly, to rename ANT as $\mathrm{ARO}$ - actant-rhizome-ontology — with reference to the Deleuzian inspiration he discerned behind Latour's formulations.

In turn, Latour's work inspired Charis Cussins' [now Thompson] work on ontological choreography in infertility treatment (Cussins 1998). Simultaneously, Andrew Pickering (1995) was writing the ontological manifesto The Mangle of Practice, and the question of how to get into view "new ontologies" (Pickering 2008) has been on his mind ever

Casper Bruun Jensen, Email: cbruunjensen@gmail.com

2Atsuro Morita, Email: morita@hus.osaka-u.ac.jp

Copyright (C) 2015 (Casper Bruun Jensen and Atsuro Morita). Licensed under the Creative Commons Attribution Non-commercial No Derivatives (by-nc-nd). Available at estsjournal.org. 
since. Several years later, Annemarie Mol (2002) brought related questions to the forefront of STS concerns with her groundbreaking The Body Multiple.

If these approaches differ in some respects, they are resonant in approaching ontologies as dynamic and emergent rather than given and static. Thus, Pickering spoke of a "performative idiom," Mol of "enactments," Cussins of "choreographies." In summary, they dealt with practical ontologies (Jensen 2004, 2010; Gad, Jensen and Winthereik 2015). Bowker and Star (1999) used this specific phrase a single time, arguing that negotiations about standards "form the basis for a fascinating practical ontology" (1999: 44-45). Bruno Latour also used it once, writing in Pandora's Hope that we are faced with "many practical metaphysics, many different practical ontologies" (Latour 1999b: 287).

The concept does not entail that such ontologies relate only to "practical issues." Instead, it means that they are about how worlds are concretely made, conjoined or transformed by the co-evolving relations of multiple agents; people, technologies, materials, spirits, ideas-or what have you. Rather than beginning from a position in the metaphysical clouds (cf. Lynch 2013) an interest in practical ontologies thus entails a "theory of the visible" (Pickering 1997).

\section{Infrastructures}

In STS, the history of technology and, more recently, anthropology, a rich literature has engaged with the infrastructures of modern societies and organizations (e.g. Edwards 2010; Hecht 2012; Wouters et al. 2012).

These studies insist that infrastructures, while certainly technical, are much more than that. Roads (Harvey and Knox 2015), waterways (Carse 2012) and databases (Bowker 2005; Jensen and Winthereik 2013) are at once culturally, socially, and economically embedded. Thus infrastructures have come to be seen as complex, heterogeneous assemblages. In the broader public imagination, infrastructures nevertheless continue to be largely seen as designed and planned technical systems. This contrast between the intentions of design and the unpredictability arising from complex interactions tends to create an oscillating view of infrastructure as simultaneously an "all-encompassing solution and an omnipresent problem, indispensable yet unsatisfactory, always already there; yet always an unfinished work in progress" (Edwards et al. 2009, 365). Since the infrastructural "work in progress" entails ongoing negotiations and contestations, Andrew Barry's (2001) term "political machines" is very apt. As we argue below, the politics of these "machines" is at once material and experimental.

The anthropologist Brian Larkin has recently defined infrastructures as

"objects that create the grounds on which other objects operate" (2013: 329). Accordingly, "their particular ontology lies in the fact that they are things and also the relation between things" (329). Although we will shortly have occasion to question Larkin's claim that infrastructures have a particular ontology, his formulation is very suggestive for thinking about their experimental dimensions and capacities.

Emphasizing that infrastructures are not only things, but also the relation between things, Larkin's description resembles nothing so much as a complex feedback loop. It is not, however, a closed loop. Infrastructures are involved in a continuous work of relating and redefining actors, from concrete and bacteria to spirits and states. Because these elements are 
extremely heterogeneous, and because their relations transform over time, infrastructural configurations are liable to unpredictable change. Moreover, what is subject to change are not only infrastructural "components" but also the forms of politics, society and environment generated by these systems. Even, the very distinction between nature and culture can be understood, to a significant extent, as a consequence of particular infrastructural arrangements (Morita 2015a).

\section{Experiments}

In STS and the history of science, a rich literature has engaged the social, material and spatial practices of scientific experiments. Segregated from ordinary social space, the laboratory has been the major physical and institutional space for such experimentation. In contrast with this well-known history of laboratory centralization, STS scholarship of recent years has pointed to the expansion of experimentation into domains such as virtual space and public debate (e.g. Edwards 2010; Marres 2013). Infrastructures can also be seen as experimental systems (Rheinberger 1994). The historian of science Hans-Jörg Rheinberger coined the term experimental system to denote the interrelated set of devices, forms of practice and organization, and conceptual frames that facilitate the making of new objects. He further showed that even though scientific experiments are in many ways highly controlled, they often generate entities and forms of knowledge planned and foreseen by no one: The resulting entities and knowledges are emergent properties of the assemblage itself.

This idea can be transposed to the terrain of infrastructures, the operations of which also bring to life novel relations and objects that do not correspond with the intentions of policy makers and engineers. In the Thai Chao Phraya delta, for example, long-stemmed rice varieties have gradually come to be seen as an integral part of amphibious infrastructure. These kinds of rice have not only shaped the regional economy and the lives of Thai farmers; due to the flood-absorbing capacities of the delta areas where the rice is grown, they are now also participants in high stakes political discussions concerning the protection of Bangkok (Morita 2015b). In other words, rice, dikes, farming practices, canals, highways and much else are simultaneously infrastructure. In turn, infrastructures hold the capacity for doing such diverse things as making new forms of sociality, remaking landscapes, defining novel forms of politics, reorienting agency, and reconfiguring subjects and objects all at once. Our characterization thus emphasizes the importance of exploring these forms of infrastructural experimentation, and the ontological patterns they form, as they emerge in the wild.

\section{Counter-points}

Michael Lynch (2013) has recently questioned what he perceives as the philosophical, nonempirical assumptions guiding the "ontological turn." Almost twenty-five years ago, Joan Fujimura (1991) described the novelty of actor-network theory similarly, as offering a new ontology, by which she meant a new theory of the world. Fujimura viewed this development positively, whereas Lynch is much more critical. What they share, however, is the idea that an interest in ontology entails adherence to a set of distinctly philosophical presuppositions (for an example of this tendency, see Barad (2007)). In contrast, we engage ontologies as (post)plural, changeable, empirical phenomena. This is also why, contrary to Brian Larkin who 
spoke of the particular ontology of infrastructure, we view infrastructures as emergent systems that produce variable practical ontologies-novel configurations of the world and its elements.

Here we can recall Andrew Barry's characterization of technological systems as "political machines." With this designation, he highlighted the significance of rethinking politics through technology. However, he also insisted on the importance of maintaining a sense of the distinctiveness of the political as a social form. Noortje Marres (2013: 421) has recently made a similar point. Arguing that STS research focusing on "empirical ontology" locates "heterogeneous actions" on a "plane of constituting phenomena," she suggested that this makes it difficult, or impossible, to see politics and democracy as also constituted through a "deliberate investment of non-humans with moral and political capacities" (422).

This dense formulation draws a contrast between two different understandings of ontology. Whereas the first sees ontological politics as an emergent effect of heterogeneous interactions, the latter emphasizes peoples' deliberate efforts to endow things with new properties. Characterizing the first of these understandings as "empirical," Marres reserves the notion of experimental ontology for her own mode of inquiry. Having defined the experimental in contradistinction to the empirical, she then further claims to go "beyond" empirical practices "in a number of ways" (423).

Due to the subtlety of these distinctions, and the overlap of terms, it is necessary to go slowly. According to Marres' typology, our depiction of infrastructures as ontological experiments would fall under the domain of the "merely" empirical. It would thus not be experimental. And it is indeed true that we see practical ontologies as emerging from empirically heterogeneous actions. Yet, Marres's (423) claim to go "beyond" the empirical makes us pause: Where is this beyond located? The experimental, we are told, is found in "efforts to purposefully design politics and morality into material objects, devices and settings" (423). Here we can make several observations.

First, rather than a move towards something new, this agenda seems to align neatly with classical work in STS: from Langdon Winner's (1986) studies of the politics embedded in technological systems to Madeleine Akrich's (1992) examination of how artifacts are scripted. Second, rather than taking us "beyond" the empirical, this kind of study seems to us instead to entail a focus on a particular dimension of the empirical. That dimension is undeniably important. Yet, it covers only a sub-set of the processes that make up what we mean by the experimental ontologies of infrastructure, which are generated through the incessant interplay between (intended) design inscriptions and the varied, unpredictable and often overlooked responses of other actors, especially a motley crew of non-humans.

Said differently, the fact that designers turn eco-homes, sewage systems or irrigation channels into infrastructural test-sites, attempting to invest these sites with particular forms of politics and morality, is neither more nor less consequential than the fact that other people, not to mention bacteria, sludge, long-stemmed rice or spirits, engage with and transform those sites in turn. Intended designs and unintended responses all happen on the same "plane." All involved entities play roles, large or small, intended or otherwise, in the ongoing transformation of the plane itself (Morita and Jensen forthcoming). 


\section{Silent Transformations}

Marres's experimental ontology, like Akrich's script analyses, and much interesting work in STS, has the merit of highlighting the political and moral investments people make in technical forms. While obviously important, this is a long-standing pre-occupation in STS, so we do not see it as the key claim to novelty of the notion of ontological experiments. To our minds, we reach that point once we examine further the issue of non-human, non-standard agency.

Ontological politics covers more than the question of how politics is embedded in technological devices, for it concerns the emergence of potentially novel political forms out of infrastructural arrangements. Careful attention to such emergence is important, not least because much that matters about ontological experiments happens as barely perceptible reconfigurations, akin to what Francois Jullien has called "silent transformations": Silent, he writes: "since 'everything' within it transforms itself, it is never sufficiently differentiated to be perceptible" (2011: 8). Silent as the rice of the Chao Phraya delta that quietly changes Thai environments and politics. Such transformations are the results of continuous recalibrations of relations. In the case of Phnom Penh's sewage infrastructures, the involved entities are as diverse as engineers and development experts, sludge and bacteria, climate conditions and the slope of the city (Jensen 2015a). Each playing a role in this unfolding infrastructural experiment, new practical ontologies emerge from the conjunction of these elements.

Yet the fact that many, if not most, of these entities and their activities tend to be "silent"- hardly noticeable, moving slowly, residing in fields or underground pipes-means that they routinely fall under the radar of public debate and controversy. In turn, this invisibility points to the limit of the notions of "vernacular categories" and "ordinary action," to which Michael Lynch (2013) reverts in his critique of ontology. As exemplified by Chao Phraya rice, the elements of ontological experiments are more than human. Other examples, like the Peruvian earth-beings described by Marisol de la Cadena (2015), or the sea serpents (Naga) inhabiting South-East Asian river infrastructures, suggest that these elements are also less than ordinary (see also Jensen 2015b).

Infrastructures, then, give rise to ontological experiments because they are sites where multiple agents meet, engage, and produce new worlds. Tracing these transformations is an effort to outline the contours of emergent ontologies. It is also an entry point for considering the core questions for a non-humanist politics: What does reality consist of? Which other creatures are we living with? And how can we live differently?

\section{Acknowledgments}

The authors would like to thank the editors and reviewers for their helpful comments. This work was supported by JSPS KAKENHI Grant Number 24251017 and the Institute for Research in Humanities, Kyoto University.

\section{References}

Akrich, M. 1992. "The De-Scription of Technical Objects.” In Shaping Technology, Building Society: Studies in Sociotechnical Change, edited by W. Bijker and J. Law, 205-224. Cambridge, MA: MIT Press.

Barad, K. 2007. Meeting the Universe Halfway: Quantum Physics and the Entanglement of Matter and 
Meaning. Durham, NC: Duke University Press.

Barry, A. 2001. Political Machines: Governing a Technological Society. London: Athlone.

Bowker, G. C. 1994. Science on the Run: Information Management and Industrial Geophysics at Schlumberger, 1920-1940. Cambridge, MA: MIT Press.

Bowker, G. C. 2005. Memory Practices in the Sciences. Cambridge, MA: MIT Press.

Bowker, G. C. and S. L. Star. 1999. Sorting Things Out: Classification and Its Consequences. Cambridge, MA: MIT Press.

Carse, A. 2012. "Nature as Infrastructure: Making and Managing the Panama Watershed." Social Studies of Science, 42(4): 539-563.

Collins, H. 1985. Changing Order: Replication and Induction in Scientific Practice. Chicago, IL: University of Chicago Press.

Cussins, C. 1998 “Ontological Choreography: Agency for Women Patients in an Infertility Clinic." In Differences in Medicine: Unraveling Practices, Techniques, and Bodies, edited by M. Berg and A. Mol, 166-202. Durham, NC: Duke University Press.

de la Cadena, M. 2015. Earth Beings: Ecologies of Practice Across Andean Worlds. Durham, NC \& London: Duke University Press.

Edwards, P. N. 2010. A Vast Machine: Computer Models, Climate Data, and the Politics of Global Warming. Cambridge, MA: MIT Press.

Edwards, P. N., G. C. Bowker, S. J. Jackson, and Robin Williams. 2009. "Introduction: An Agenda for Infrastructure Studies. Journal of the Association for Information Systems 10(5): 364-374.

Fujimura, J. 1991. “On Methods, Ontologies and Representation in the Sociology of Science: Where Do We Stand?" In Social Organization and Social Process: Essays in Honor of Anselm Strauss, edited by D. Maines, 207-249. New York: De Gruyter.

Gad, C., C. B. Jensen and B. R. Winthereik. 2015. "Practical Ontology: Worlds in STS and Anthropology. NatureCultures 3: 67-86.

Gooding, D. 1990. Experiment and the Making of Meaning: Human Agency in Scientific Observation and Experiment. Dordrecht, Boston, \& London: Klüwer Academic Publishers.

Harvey, P. and H. Knox. 2015. Roads: An Anthropology of Infrastructure and Expertise. Ithaca, NY \& London: Cornell University Press.

Hecht, G. 2012. Being Nuclear: Africans and the Global Uranium Trade. Cambridge, MA: MIT Press \& Wits University Press.

Holbraad, M., M. A. Pedersen, and E. Viveiros de Castro. 2014. "The Politics of Ontology: Anthropological Positions." Fieldsights - Theorizing the Contemporary, Cultural Anthropology Online, January 13, 2014. Available at: http: / / culanth.org / fieldsights / 462-the-politics-of-ontology-anthropologicalpositions.

Hughes, T. P. 1983. Networks of Power: Electric Supply Systems in the US., England and Germany, 18801930. Baltimore, MD: Johns Hopkins University Press.

Jensen, C. B. 2004. “A Non-Humanist Disposition: On Performativity, Practical Ontology, and Intervention". Configurations 12: 229-61.

Jensen, C. B. 2010. Ontologies for Developing Things: Studying the Generation of Futures in Health Care. Rotterdam: Sense

Jensen, C. B. and B. R. Winthereik. 2013. Monitoring Movements in Development Aid: Recursive Infrastructures and Partnerships. Cambridge, Ma \& London: MIT Press. 
Jensen, C. B. 2015a. "Pipe Dreams: Activity Trails, Infra-Reflexivity and Sewage in Phnom Penh". Ethnos (Special issue: Infrastructures as Ontological Experiments).

Jensen, C. B. 2015b. "Experimenting with Political Materials: Environmental Infrastructures and Ontological Transformations". Distinktion: Scandinavian Journal of Social Theory (Special issue: Political Materials: Rethinking Environment, Remaking Theory). 16(1): 17-30.

Jullien, F. 2011. The Silent Transformations. London, New York \& Calcutta: Seagull.

Larkin, B. 2013. "The Politics and Poetics of Infrastructure." Annual Review of Anthropology 42: 327-43.

Latour, B. 1988. The Pasteurization of France. Cambridge: Cambridge University Press.

Latour, B. 1999a. "On Recalling ANT." In Actor-Network Theory and After, edited by J. Law and J. Hassard, 15-25. Oxford: Blackwell Publishers.

Latour, B. 1999b. Pandora's Hope: Essays on the Reality of Science Studies. Cambridge, MA: Harvard University Press.

Lynch, M. 2013. "Ontography: Investigating the Production of Things, Deflating Ontology." Social Studies of Science 43(3): 444-462.

Marres, N. 2013. “Why Political Ontology Must Be Experimentalized: On Eco-Homes as Devices of Participation." Social Studies of Science 43(3): 417-43.

Mol, A. 2002. The Body Multiple: Ontology in Medical Practice. Durham, NC \& London: Duke University Press.

Morita, A. 2015a. "Multispecies Infrastructure: Infrastructural Inversion and Involutionary Entanglements in the Chao Phraya Delta, Thailand." Ethnos (Special issue: Infrastructures as Ontological Experiments).

Morita, A. 2015b. "Infrastructuring the Amphibious Space: The Interplay of Aquatic and Terrestrial Infrastructures in the Chao Phraya Delta in Thailand." Science as Culture (Special issue: Infrastructuring Environments).

Morita, A. and C. B. Jensen. Forthcoming. “Delta Ontologies: Infrastructural Transformations in Southeast Asia." Social Analysis (Special issue: Multiple Nature-Cultures, Diverse Anthropologies).

Pickering, A. 1995. The Mangle of Practice: Time, Agency and Science. Chicago, IL \& London: University of Chicago Press.

Pickering, A. 1997. “Time and a Theory of the Visible." Human Studies 20: 325-33.

Pickering, A. 2008. "New Ontologies." In The Mangle in Practice: Science, Society, and Becoming, edited by Pickering, Andrew and Keith Guzik, 1-17. Durham, NC \& London: Duke University Press.

Rheinberger, H-J. 1994. “Experimental Systems: Historiality, Narration, and Deconstruction.” Science in Context 7(1): 65-81.

Shapin, S. and S. Shaffer. 1985. Leviathan and the Air-Pump: Hobbes, Boyle, and the Experimental Life. Princeton, NJ: Princeton University Press.

Winner, L. 1986. The Whale and the Reactor: A Search for Limits in an Age of High Technology. Chicago, IL: University of Chicago Press.

Woolgar, S., and J. Lezaun. 2013. “The Wrong Bin Bag: A Turn to Ontology in Science and Technology Studies." Social Studies of Science 43(3): 321-40.

Wouters, P., A. Beaulieu, A. Scharnhorst and S. Wyatt. 2012. Virtual Knowledge: Experimenting in the Humanities and the Social Sciences. Cambridge, MA \& London: MIT Press. 